PRINT ISSN 1119-8362

Electronic ISSN 1119-8362
Full-text Available Online at

https://www.ajol.info/index.php/jasem

http://ww.bioline.org.br/ja
J. Appl. Sci. Environ. Manage.

Vol. 25 (5) 773-777 May 2021

\title{
Geochemical Maturity and Paleo-Weathering Indices of Sedimentary Succession in JV- Field Greater Ughelli Depo-Belt Niger Delta Basin
}

\author{
LUCAS, FA; "FREGENE, TJ
}

\author{
Department of Geology, University of Benin, Benin City, Nigeria \\ *Corresponding AuthorEmail: drfalucas@gmail.com,talktobabat4us@yahoo.com
}

\begin{abstract}
This study evaluates the geochemical maturity and paleo weathering indices of X well JV-Field, Greater UghelliDepo belt Niger Delta Basin, using reflected light microscope and geochemical proxies. The data obtained identified three lithofacies units as Sand, Shale, and Shaly sand facies.The application of source area weathering using Chemical index of alteration (CIA) and Chemical index of weathering (CIW) values for the sampled intervals ranges from (48.6-94.9\%) and (60.6-96.7\%), and have median values of (83.2 and 90.3) \% respectively which is an indication of high weathering at the source. The values are variable and it may be as a result of multiple provenances of the sediments which have variable proportions of source area weathering and related processes or may be due to low concentrations of the alkalis and alkaline earth elements. However, all the samples excluding one with depth (12430ft) show CIA and CIW values greater than $70 \%$ indicating high (intensive) weathering either at the source or during transportation before deposition .From the high alteration indices value recorded from the sampled intervals, it can be inferred that the sediments are geochemically and texturally mature.
\end{abstract}

\section{DOI:https://dx.doi.org/10.4314/jasem.v25i5.12}

Copyright: Copyright $\odot 2021$ Lucas and Fregene. This is an open access article distributed under the Creative Commons Attribution License (CCL), which permits unrestricted use, distribution, and reproduction in any medium, provided the original work is properly cited.

Dates: Received: 20 March 2021; Revised: 27 April 2021; Accepted: 07 May 2021

Keywords: Geochemical maturity, chemical index, weathering, sedimentary rock

The Niger Delta is the most significant hydrocarbon province on the West African continental margin. It lies mainly in the Gulf of Guinea to the southwest of the Benue - Trough and constitutes the most important Cenozoic deltaic construction in the south Atlantic. Because of its petroliferous nature, the economy of Nigeria depends largely on the oil and gas derived from it. The Cenozoic Niger Delta is situated at the intersection of the Benue Trough and the South Atlantic Ocean where a triple junction developed during the separation of South America and Africa in the Late Jurassic (Whiteman, 1982). Geologically it is found in the Tertiary period in the geologic column. The mineralogical and chemical composition of clastic sedimentary rocks are controlled by various factors, including :The composition of their source rocks,environmental parameters influencing the weathering of source rocks (e.g., atmospheric chemistry, temperature, rainfall and topography), Duration of weathering and transportation mechanisms of clastic material from source region to depocenter, depositional environment (e.g., marine versus fresh water) and Post-depositional processes (e.g. diagenesis, metamorphism). It is a technique used to correlate sedimentary successions based on subtle changes in concentration of key major, minor and trace elements (Lucas et al., 2016).
This study evaluates the geochemical maturity and paleo weathering indices of X well JV-Field, Greater Ughelli Depo belt Niger Delta Basin, Nigeria.

\section{MATERIALS AND METHOD}

Ten (10) Ditch Cutting samples were collected from the Agbada Formation at different intervals between 4100ft and 12430ft from JVX- Well Niger Delta, and were lithologically described using a reflected light microscope in order to obtain the texture, sorting, color, and shapes/roundness and post depositional diagenetic effect. These properties are vital for the analysis of lithofacies. Consequently a Geological model embracing Lithofacies was generated for the Well's sedimentary succession. The Sampled intervals were from the Agbada Formation. The samples there after were prepared using standard geochemical sample processing technique and analyzed for further studies.

Sample preparation for XRF analysis: The samples were pulverized, Pellets were prepared from the pulverized sample by mixing the powdered sample (10 $\mathrm{g}$ ) with $1 \mathrm{~g}$ of stearic acid (binder) and thoroughly homogenized in an agate mortar. Stearic acid is an organic binder which increases mechanical stability of the sample. The mixture was then transferred into a 40 
$\mathrm{mm}$ in-diameter hardened steel disc and pressed into a pellet at a pressure of 25 tons using hydraulic pressure press. The pellet were loaded into each sample holder of the X-ray machine for analysis. Minipal 4 EDXRF at NGRL Kaduna was used for the analysis. This method operates on the principle of atomic physics and quantum chemistry. The specimens were exposed to the entire spectrum of photons consisting of primary radiation emitted from a standard $\mathrm{x}$-ray tube which irradiated each specimen causing the element in it to emit secondary fluorescence with their characteristics $\mathrm{x}$-ray line spectra. The spectral line energies or wavelength of the emitted lines was used in the quantitative analysis of elements in the specimen. The intensities of the emitted lines were related to their elemental concentration. X-ray fluorescence method was used to determine the concentration of major and trace element in order to infer the environment of deposition.

Sample preparation for AAS analysis: $1 \mathrm{~g}$ of the powdered sample was weighed into a beaker and digested with $30 \mathrm{ml}$ of concentrated hydrochloric acid and $10 \mathrm{ml}$ of nitric acid on the thermostat regulated hot plate inside the fume cabinet. The digested sample was filtered using whatman filter paper into a $100 \mathrm{ml}$ plastic bottle and the volume made up to mark with distilled water. The sample solution was analyzed for the minor and trace elements by AAS. The elements standard solutions and their hollow cathode lamps were used for plotting calibration graphs after which the sample solution was aspirated into the Spectrometer.
Chemical Weathering Calculations: A good measure of the degree of chemical weathering was obtained by calculation of the Chemical index of alteration (CIA), Plagioclase index of alteration (PIA) and Chemical index of weathering (CIW) (Nesbitt and Young, 1982; Fedo et al., 1995). These are the most widely used indices for quantitative estimation of the degree of chemical weathering undergone by the rocks from the provenance area of clastic sediments, which gives an indication of the degree of weathering in the source region (Nesbitt and Young, 1982). Other indices that can also be used are the Ruxton Ratio (RR). High CIA, PIA, and CIW values (i.e. 75-100) indicate intensive weathering in the source area, whereas low values (i.e. 60 or less) indicate low weathering in the source area.

The $\mathrm{CIA}=100\left[\mathrm{Al}_{2} \mathrm{O}_{3} /\left(\mathrm{Al}_{2} \mathrm{O}_{3}+\mathrm{CaO}+\mathrm{Na}_{2} \mathrm{O}+\mathrm{K}_{2} \mathrm{O}\right)\right]$

The PIA $=100\left[\left(\mathrm{Al}_{2} \mathrm{O}_{3}-\mathrm{K}_{2} \mathrm{O}\right) /\left(\mathrm{Al}_{2} \mathrm{O}_{3}+\mathrm{CaO}+\mathrm{Na}_{2} \mathrm{O}-\right.\right.$ $\left.\mathrm{K}_{2} \mathrm{O}\right]$

The $\mathrm{CIW}=100\left[\mathrm{Al}_{2} \mathrm{O}_{3} /\left(\mathrm{Al}_{2} \mathrm{O}_{3}+\mathrm{CaO}+\mathrm{Na}_{2} \mathrm{O}\right)\right]$

The $\mathrm{RR}=\mathrm{SiO}_{2} / \mathrm{Al}_{2} \mathrm{O}_{3}$

\section{RESULT AND DISCUSSION}

Lithologic Description: Samples collected and analyzed using a reflected light microscope shows that the sampled intervals were from the Agbada Formations which comprises of shale and sand intercalation. lithofacies units gotten from sampled intervals are Sand, Shale, and Shaly sand facies respectively..

Table 1: Showing results of Major element compositions (wt. \%) for sampled intervals of the well

\begin{tabular}{|c|c|c|c|c|c|c|c|c|c|c|}
\hline $\begin{array}{l}\% \quad \text { Oxide } \\
\text { Composition }\end{array}$ & $4100 \mathrm{ft}$ & $4900 \mathrm{ft}$ & $5270 \mathrm{ft}$ & $6930 \mathrm{ft}$ & $8149 \mathrm{ft}$ & $8606 \mathrm{ft}$ & $11080 \mathrm{ft}$ & $11700 \mathrm{ft}$ & $11831 \mathrm{ft}$ & $12430 \mathrm{ft}$ \\
\hline $\mathrm{SiO}_{2}$ & 93.55 & 93.37 & 62.09 & 61.99 & 36.19 & 71.18 & 50.90 & 35.14 & 77.56 & 93.22 \\
\hline $\mathrm{TiO}_{2}$ & 0.30 & 0.15 & 0.521 & 4.33 & 1.91 & 2.66 & 3.28 & 1.09 & 0.722 & 0.554 \\
\hline $\mathrm{Al}_{2} \mathrm{O}_{3}$ & 1.70 & 1.90 & 14.11 & 13.51 & 14.27 & 15.20 & 12.61 & 14.70 & 4.33 & 1.40 \\
\hline $\mathrm{Fe}_{2} \mathrm{O}_{3}$ & 1.760 & 0.973 & 5.523 & 4.26 & 19.76 & 3.33 & 9.64 & 30.41 & 2.954 & 0.905 \\
\hline $\mathrm{SO}_{3}$ & $\mathrm{Nd}$ & $\mathrm{Nd}$ & 8.14 & $\mathrm{Nd}$ & 22.50 & $\mathrm{Nd}$ & 10.20 & $\mathrm{Nd}$ & 3.12 & $\mathrm{Nd}$ \\
\hline $\mathrm{Cl}$ & $\mathrm{Nd}$ & 0.914 & $\mathrm{Nd}$ & $\mathrm{Nd}$ & $\mathrm{Nd}$ & $\mathrm{Nd}$ & 0.67 & $\mathrm{Nd}$ & 0.646 & $\mathrm{Nd}$ \\
\hline $\mathrm{Br}$ & 0.010 & $\mathrm{Nd}$ & 0.008 & $\mathrm{Nd}$ & $\mathrm{Nd}$ & $\mathrm{Nd}$ & 0.002 & 0.02 & $\mathrm{Nd}$ & 0.009 \\
\hline $\mathrm{CaO}$ & 0.16 & 0.010 & 0.095 & 0.16 & 0.765 & 0.15 & 3.24 & 3.76 & 0.037 & 0.091 \\
\hline $\mathrm{MgO}$ & 0.11 & 0.007 & 0.04 & 0.033 & 0.12 & 0.023 & 0.35 & 0.79 & 0.010 & 0.013 \\
\hline $\mathrm{Na}_{2} \mathrm{O}$ & 0.008 & 0.073 & 0.391 & 1.384 & 0.65 & 1.30 & 1.29 & 0.47 & 0.54 & 0.57 \\
\hline $\mathrm{K}_{2} \mathrm{O}$ & 0.005 & 0.020 & 0.479 & 1.686 & 0.75 & 1.08 & 0.81 & 0.36 & 0.76 & 0.82 \\
\hline $\mathrm{MnO}$ & 0.003 & $<0.001$ & $<0.001$ & $<0.001$ & 0.057 & 0.017 & 0.070 & 0.48 & $<0.001$ & $<0.001$ \\
\hline $\mathrm{V}_{2} \mathrm{O}_{5}$ & 0.013 & 0.034 & 0.01 & 0.084 & 0.03 & 0.02 & $\mathrm{Nd}$ & 0.03 & 0.01 & 0.01 \\
\hline $\mathrm{Cr}_{2} \mathrm{O}_{3}$ & 0.019 & 0.040 & 0.016 & 0.033 & 0.021 & 0.014 & $\mathrm{Nd}$ & 0.005 & 0.021 & $<0.001$ \\
\hline $\mathrm{CuO}$ & 0.021 & 0.022 & 0.023 & 0.040 & 0.033 & 0.023 & 0.055 & 0.044 & 0.011 & 0.018 \\
\hline $\mathrm{ZnO}$ & $\mathrm{Nd}$ & 0.037 & 0.008 & 0.046 & 0.034 & 0.011 & 0.062 & 0.033 & $\mathrm{Nd}$ & $\mathrm{Nd}$ \\
\hline $\mathrm{Ga}_{2} \mathrm{O}_{3}$ & $\mathrm{Nd}$ & 0.005 & $\mathrm{Nd}$ & 0.009 & $\mathrm{Nd}$ & $\mathrm{Nd}$ & $\mathrm{Nd}$ & $\mathrm{Nd}$ & $\mathrm{Nd}$ & $\mathrm{Nd}$ \\
\hline $\mathrm{Rb}_{2} \mathrm{O}$ & $\mathrm{Nd}$ & $\mathrm{Nd}$ & $\mathrm{Nd}$ & 0.038 & 0.030 & 0.014 & 0.047 & 0.01 & 0.011 & 0.010 \\
\hline $\mathrm{SrO}$ & 0.014 & 0.016 & 0.018 & 0.099 & 0.073 & 0.048 & $\mathrm{Nd}$ & 0.066 & 0.026 & 0.038 \\
\hline $\mathrm{ZrO}_{2}$ & 0.029 & 0.026 & 0.055 & 0.547 & 0.17 & 1.15 & 0.25 & 0.20 & 0.098 & 0.075 \\
\hline $\mathrm{BaO}$ & 0.075 & 0.19 & 0.07 & $\mathrm{Nd}$ & 0.23 & 0.70 & 0.70 & 0.49 & 0.31 & 0.53 \\
\hline $\mathrm{PbO}$ & 0.018 & 0.017 & $\mathrm{Nd}$ & 0.043 & 0.11 & 0.020 & 0.13 & 0.17 & 0.020 & 0.027 \\
\hline $\mathrm{As}_{2} \mathrm{O}_{3}$ & 0.008 & 0.001 & $\mathrm{Nd}$ & 0.003 & $\mathrm{Nd}$ & 0.010 & $\mathrm{Nd}$ & $\mathrm{Nd}$ & 0.007 & 0.005 \\
\hline $\mathrm{Ta}_{2} \mathrm{O}_{5}$ & $\mathrm{Nd}$ & $\mathrm{Nd}$ & $\mathrm{Nd}$ & $\mathrm{Nd}$ & $\mathrm{Nd}$ & $\mathrm{Nd}$ & $\mathrm{Nd}$ & 0.03 & $\mathrm{Nd}$ & $\mathrm{Nd}$ \\
\hline L.O.I. & 2.20 & 2.20 & 8.40 & 11.70 & 2.30 & 3.05 & 15.70 & 11.70 & 8.80 & 1.70 \\
\hline
\end{tabular}




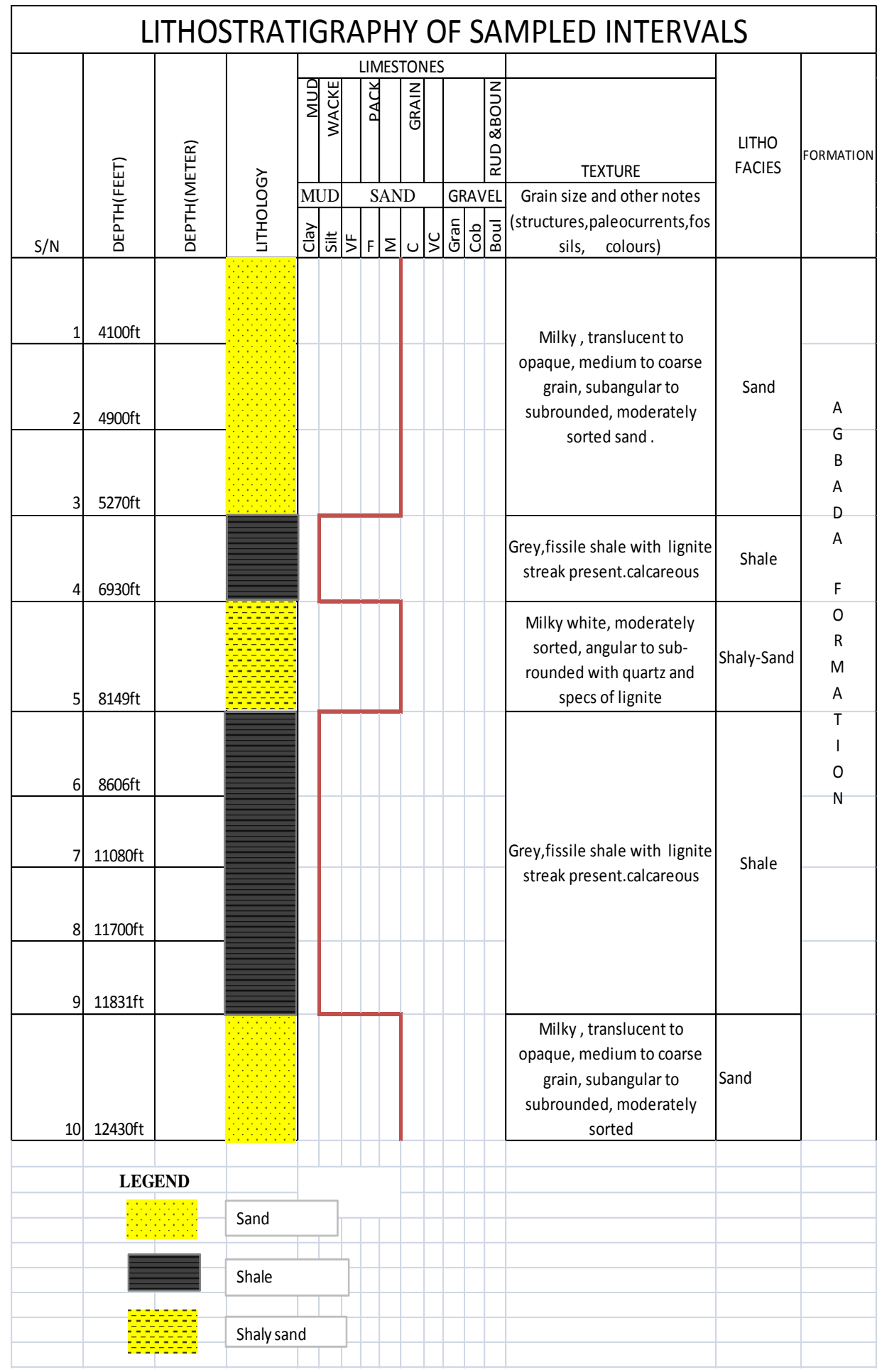

Fig 1: Lithologic description of the sampled intervals

The sands are Milky, translucent to opaque, medium to coarse grain, sub-angular to sub-rounded, moderately sorted sand while the shales are Grey in colour, fissile with presence of lignite streak it is calcareous. CIA and CIW values for JVX well ranges from $(48.6-94.9 \%)$ and $(60.6-96.7 \%)$, and have median values of (83.2 and 90.3)\% respectively which is an indication of high weathering at the source (See Table 4.19). The values are variable and it may be as a result of multiple provenances for the sediments which have variable proportions of source area weathering and related processes or may be due to low 
concentrations of the alkalis and alkaline earth elements. However, all the samples excluding one with depth (12430) show CIA and CIW values greater than $70 \%$ indicating high (intensive) weathering either at the source or during transport before deposition (McLennan, 1993; Fedo et al., 1995).

Table 2: Showing Chemical Index of Alteration (CIA) and Chemical Index of Weathering (CIW) values for JVX well

\begin{tabular}{|c|c|c|}
\hline DEPTH (FT) & $\begin{array}{l}\text { Chemical Index of } \\
\text { Alteration (CIA) }\end{array}$ & $\begin{array}{l}\text { Chemical Index of } \\
\text { Weathering (CIW) }\end{array}$ \\
\hline 4100 & 90.9 & 91.0 \\
\hline 4900 & 94.9 & 95.8 \\
\hline 5270 & 93.6 & 96.7 \\
\hline 6930 & 80.7 & 89.7 \\
\hline 8149 & 86.8 & 90.9 \\
\hline 8606 & 85.7 & 91.3 \\
\hline 11080 & 70.3 & 73.7 \\
\hline 11700 & 76.2 & 77.6 \\
\hline 11831 & 76.4 & 88.2 \\
\hline 12430 & 48.6 & 60.6 \\
\hline
\end{tabular}

Table 3: Showing data's of $\mathrm{SiO}_{2}$ and $\mathrm{Al}_{2} \mathrm{O}_{3}+\mathrm{K}_{2} \mathrm{O}+\mathrm{Na}_{2} \mathrm{O}$ of the sampled intervals

\begin{tabular}{lll} 
& \multicolumn{3}{c}{ DEPTH (FT) } & $\mathbf{S i O}_{\mathbf{2}}$ & $\mathbf{A l}_{\mathbf{2}} \mathbf{O}_{\mathbf{3}}+\mathbf{K}_{\mathbf{2}} \mathbf{O}+\mathbf{N a}_{\mathbf{2}} \mathbf{O}$ \\
\hline 4100 & 93.55 & 1.713 \\
4900 & 93.37 & 1.993 \\
5270 & 62.09 & 14.98 \\
6930 & 61.99 & 16.58 \\
8149 & 36.19 & 15.67 \\
8606 & 71.18 & 17.58 \\
11080 & 50.90 & 14.71 \\
11700 & 35.14 & 15.53 \\
11831 & 77.56 & 5.63 \\
12430 & 93.22 & 2.79 \\
\hline
\end{tabular}

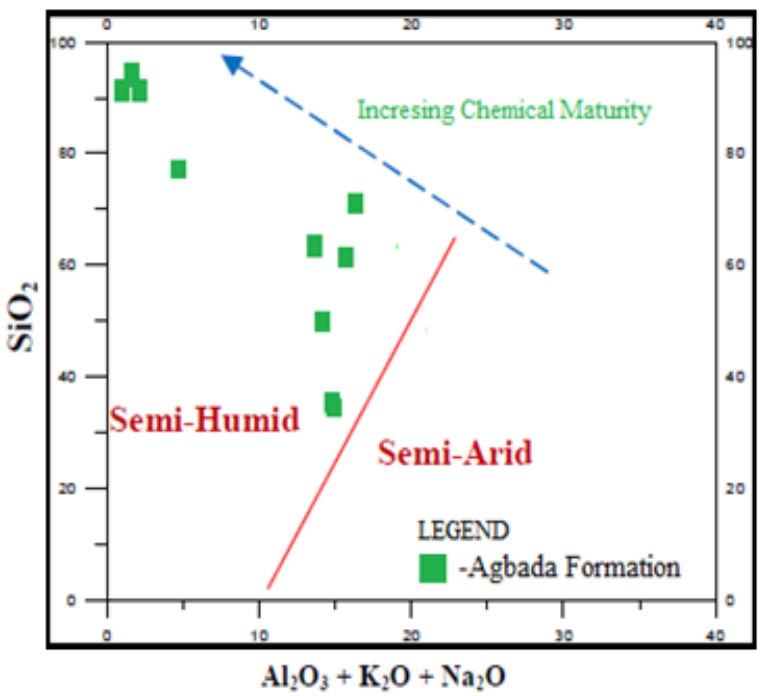

Fig 2: Chemical maturity of sediments from JVX well expressed by bivariate plot of $\mathrm{SiO}_{2}$ versus $\left(\mathrm{AL}_{2} \mathrm{O}_{3}+\mathrm{K}_{2} \mathrm{O}+\mathrm{Na}_{2} \mathrm{O}\right)$ showing trend of Maturity (after Suttner and Dutta, 1986)

The low variation in CIA values of depth (12430) may reflect changes in the proportion of feldspars and the various clay minerals in the analyzed samples. Size sorting during transportation and deposition generally results in some degree of mineral differentiation, which may modify the CIA (Pettijohn, 1975; Nesbit and Young, 1982).From the high alteration indices, it can be inferred that the sediments are geochemically and texturally mature.A Bivariant Plot of $\mathrm{SiO}_{2}$ against total $\left(\mathrm{Al}_{2} \mathrm{O}_{3}+\mathrm{K}_{2} \mathrm{O}+\mathrm{Na}_{2} \mathrm{O}\right)$ proposed by Suttner and Dutta, 1986 (Fig.1) was used in order to identify the chemical maturity of the sediments from the well as a function of climate. The plots revealed semi-humid conditions for the samples. The paleoclimatic condition of the samples display wet condition which accelerates weathering process and speeds up the chemical maturity.

Conclusion:The application of source area weathering using CIA and CIW, shows that the samples havemoderate to high (intensive) weathering either at the source or during transportation before deposition. The high alteration indices value recorded from the sampled intervals inferred that the sediments are geochemically and texturally mature. Semi-humid conditions was suggested for the sampled intervals of the well. The paleoclimatic condition of the samples display wet condition which accelerates weathering process and speeds up chemical maturity.

Acknowledgement: The authors are grateful to Nigerian Petroleum Development Company (NPDC) Benin and National Geosciences Research Laboratories (NGRL) Kaduna for their assistance in this research.

\section{REFERENCE}

Fedo, CM; Nesbitt, HW; Young, GM (1995). Unraveling the effects of potassium metasomatism in sedimentary rocks and Palaesols, with implications for paleoweathering conditions and provenance. Geo 23.921- 924.

Germeraad, JB; Bopping, CA;MulIer, J(1968). Palynology of Tertiary Sediments from Tropical areas. Rev. Paleobotan. Palynol. 6. 189 - 348.

Lucas, FA et al., (2016). Chemostratigraphy: Major/Minor Elemental Ratio Trends in Goml-1 Well Benin Flank in the Northern Delta Depobelt Nigeria (A Case Study of $\mathrm{Na}$ : $\mathrm{Zn}$ and K: Mn.).Basic. Appl.Res. 28 (3) 204-216.

Mclennan, SM; Hemming, S; McDaniel, DK; Hanson, GN (1993). Geochemical approaches to sedimentation, provenance, and tectonics. Processes controlling the composition of clastic sediments (Johnson, M.J. and Basu, A., eds.), 21 40, Geological. Society of America special paper 284. 
Nesbitt, HW; Young, GM (1982). Early Proterozoic Climate and Plate motion inferred from major element chemistry of lutites, Nature 299. 715 717.

Pettijohn, FJ (1975). Sedimentary Rocks. 2nd ed. New York, NY, USA: Harper and Row.

Stacher, P (1995). Present understanding of the Niger Delta hydrocarbon habitat, In: Oti, M. N. and Postma, G. (Eds.), Geology of Deltas: Rotterdam, A.A. Balkema, p. 257-267.
Suttner and Dutta, 1986. Alluvial sandstone composition and paleoclimate. J. Sedi. Res. (1986) 56 (3): 329-345

Whiteman, AJ (1982). Nigeria: Its Petroleum Geology, Resources and Potential. Graham and Trotman, London. p. 1-394. 